\title{
The Central Bank of Jordan and Its Relation with Other Islamic Banks in Jordan
}

\author{
Saeed Mikhled Ahmad Al-Naimat ${ }^{1}$ \\ ${ }^{1}$ Department of Accounting \& Accounting Information System, Amman University College for Financial \& \\ Administrative Sciences, Al-Balqaa Applied Sciences University, Jordan \\ Correspondence: Saeed Mikhled Ahmad Al-Naimat, Department of Accounting \& Accounting Information \\ System, Amman University College for Financial \& Administrative Sciences, Al-Balqaa Applied Sciences \\ University, Amman, Jordan. E-mail: Saeed_alnaimat@hotmail.com
}

Received: January 22, 2013

Accepted: February 19, 2013

Online Published: April 23, 2013

doi:10.5539/ijbm.v8n9p140

URL: http://dx.doi.org/10.5539/ijbm.v8n9p140

\begin{abstract}
This research investigates the relationship between the central bank of Jordan and other working banks in Jordan, to achieve this objective the researcher had reviewed the control means used with Islamic Banks compared to other commercial Banks upon which we eahzed the presence of some Inefficiencies that impacted the Islamic banks performance negatively (the Dimension were shown in the paper).

With the aim of enhancing the current situation the researcher, had reviewed a group of laws regarding upon the Data collected and analyzed, the researcher ended with a group of recommendations which will contribute in making the central bank review new components for the favors of the Islamic banks which will lead to more investment of liquid.
\end{abstract}

\section{Introduction}

Islamic and Arab worlds The had witnessed a wide-spread of traditional banks, these banks base their activities on the principle of Interest rate which pushed Islamic scholars to object and Fight the spread of this type of usury practiced by these led to the presence of Islamic banks that base its activities on Islamic sharite.

So Malaysia was the place of the First Islamic activity in 1940 when it had found saving Funds in that work according to sharite (with out interest rate) in 1950, It was the First methodological thinking about Determining Financial Instruments based upon Islamic sharite in Pakistan.

While the experience of Dr. Ahmad alnajjar in" neat gamer" in south eyypt in 1963 in the saving banks the First experiment in the Arab world, which aimed For local Development Also umm Dorman university started to teach a course about Islamic economy in the same year as an another Islamic economy experiment - which resulted in adoption of "non usury banks" project, then in 1971 Nasser bank emerged in Egypt also in 1975 the Islamic bank of Development in Jeddah was established, as an international Foundtion for developmental financing, by making researches, Developing commerce internally and externally and providing training and other activities upon the contribution of all Islamic is states. At the same year dubai Islamic bank was found upon a Discretion of Dubai government and after that there were many Islamic banks the appeared here.

\subsection{Statement of Problem}

the central bank of Jordan adoption for a single control method to the traditional and Islamic working method to the Traditional and Islamic working banks in Jordan like the Legal reserve, the Legal level of Liquidity, The Credit ciellings, rediscounting, and the last creditor were some of the monetary policies applied by the central bank and Impacting the Islamic banks negatively consequently weakening the profit distribution percentages of the investment accounts, because their banking Transactions Differ form the traditional banks and Inspite of this condition its dealt with by the came monetary policy of the central bank.

\subsection{The Objectives}

The study aims to investigate the relation between the Islamic banks working in Jordan and the central bank of Jordan which is represented by the Following Points:

1) Defining the Control of Central bank of Jordan concept on the Islamic banks in Jordan, Instruments and 
motives.

2) Determining the most Important problems resulting Form the Implementation of the same control methods with the Islamic and commercial banks and the impact of it on the Islamic banks.

3) Reviewing some of the laws regarding Islamic banks applied in other Arab and Islamic states and what distinguishes if from commercial banks at these countries.

4) Comparing these laws with those applied in Jordan and Figuring out ways that can solve the Jordanian Islamic banks problem.

5) Presenting the appropriate recommendations a bout implementing the control Instruments that suit the Islamic banks work in Jordan because it differs Form that of the traditional banks.

\subsection{Hypotheses}

1) H0: This is no statistical significant relation between implementing unique control policy on the Islamic and commercial banks and efficiency of the Islamic banks performance.

2) H1: there is a statistical significant relation between implementing a unique control policy for traditional and Islamic banks and the efficiency of the Islamic banks performance.

3) H0: there is no statistical significant relation between the Islamic banks performance and non abiding to the laws Issued by the central bank regarding its requisites.

4) H0: there is statistical significant relation between the Islamic banks performance and non abiding to the laws Issued by the central bank regarding its requisites.

5) H0: there is no statistical significant relation between solving the Problems Facing Jordanian Islamic banks by adopting laws of Islamic banks in other states.

6) H0: there is statistical significant relation between the Islamic banks performance and non abiding to the laws Issued by the central bank regarding its requisites.

7) Ho: There is no Statistical significant relation between applying the suggested points that snit the Islamic banks and Improving the Islamic banks performance.

8) Ho: There is Statistical significant relation between applying the suggested points that snit the Islamic banks and Improving the Islamic banks performance.

\subsection{The Sample}

The study sample will be limited to the two banks working in the central bank of Jordan: The International Arab Islamic bank and the Jordan Islamic bank.

\subsection{Data Collection}

The researcher had clopped several Data collection methods like:

A. Reviewing the laws and Jurisdictions organizing the Islamic banks works in Jordan.

B. Holding personal Interviews with the workers of the central bank of Jordan and the administration of the Jordan Islamic bank and the International Arab Islamic bank.

C. Using a questionnaire containing a group of items Directed for the bank workers in the central bank of Jordan, the International Arab Islamic bank and Jordan Islamic bank.

\subsection{The Limitations}

Upon the fact that this research is applied on the Islamic banks working in Jordan, the study Population will be limited to the control Instruments of the central bank of Jordan used with the this Islamic banks working in Jordan: the Jordan Islamic bank and the international Arab Islamic bank.

\section{The Literature}

In spite of the claims made by the central bank a bout having special standards and measures which is reflected by the many researches and views regarding this Issue and the study will Deal with some of it here as Follows:

(She hadeh, 2002) was about the Islamic banks with the central banks, the study aimed to providing special criteria by the central bank of Jordan For the evaluation of the Islamic banks performance by shedding the Light on some of the central control actives and the nature of the Islamic banks activities and concluded the study with some recommendations about increasing the control efficiency like the necessity of the control efficiency like the necessity of recognizing the Islamic banks activities and nature by monetary authorities when choosing the 
by the monetary authorities when choosing the practical Instructions and controlling those banks to avoid any bias in Dealing with these banks which will enable the Islamic banks to use its resources efficiently and contributing in Developing the national economy.

In another study (1994) For him also he Pointed that ACL opting the same liquidity ratios by the central banks as a control Instrument for the Islamic banks as the Traditional banks In spite of the Difference in the ratios of the numerator will be a bias against the Islamic banks because it doesn't deal with Treasury bonds (as the Traditional banks) while it is one of the ratios of numerator and recommending the adoption of the stocks within the ratios Instead of Treasury bonds besides the obstacles of providing Finance From the Central banks when necessary because of the Interest paid here and recommended that some capitals can be Deposited based upon the speculation basis in the central bank as it is made in Bangladesh and Mauritania.

(Shawish, 2000) was about the relation between Islamic banks and the central bank and pointed to the no - use of the Islamic banks from the rediscount rate because this Instrument contradicts with the nature of the Islamic banks activity because its Reba (usury).

(Alamayreh, 1991) made a study pointed in it-while speaking about the relation of the Islamic banks with the central bank-that the open marked policy contradicts with the Islamic banks activity because the treasury bonds have Interest rate and pointed that using credit or murababa bond Instead of it will be the best solution because of its permission in Islamic.

(Al-sartawi, 2002) made a study the relation between the central bank with the Islamic banks at which the researcher shed the light on the concept of central bank and the policy adopted by it to control banks (Islamic and traditional) and the nature of the relation between them, the study aimed for providing a solution that enable the central bank of controlling banks without affecting the specifity of Islamic banks and concluded it with a group of recommendations of this side.

And in an internal study of (tradd, 2002) about the relation of Islamic banks to the central bank given for the researcher as a support for the paper-the researcher shed the lights on control Instruments adopted by the shed light on control Instruments adopted by the central bank of Jordan regarding the Islamic bank, pointed to the most Important problems facing them and the recommendations made by Islamic financials and researchers to solve it and concluded that the control instruments adopted must be adjusted and Implementing new tools for the benefit of the Islamic banks.

\subsection{The Setting:The Islamic Banks Emergence in Jordan}

The central bank is the top of the banking Industry in Jordan and the monetary authority in the kingdom, aims to stabilize the monetary conditions and the exchange rate of the Jordanian Dinar, supporting the Increasing economic growth and licensing banks in Jordan at which these were 24 working banks in Jordan: 14 commercial and (8) Foreign banks besides Two Islamic banks.

Regarding the Islamic two banks: the First was the Jordan Islamic bank Found in 1978 under ate moray law which was changed to especial draft regarding the Islamic banks item 28 for 2000, that was adopted in 1/8/2000, while the second was the international Arab Islamic bank found in 1997 and started work in 9/2/ 1998.

\subsection{The Central Bank and Its Functions}

The central bank of Jordan was found in 1964 at the first of October of the same year. With two subsidiaries for it: the first in the north in Irbid while the second in the south in Aqaba to facilitate the work of the commercial Banks subsidiaries and other governmental establishments in all around the kingdom with the central bank as a type of managerial decentralization. The central bank of Jordan is regarded as the monetary authority of the kingdom and the top of the bank industry of Jordan of Jordan having distinct representation.

It works as the state bank and for the other banks, Issuing banknotes by managing the banking Industry reserves, the credit type and size besides supervising the working commercial banks in Jordan to achieve its goals represented by the monetary stabilization of the kingdom and supporting the Jordanian exchange rate guaranteeing the Increasing economic Garth according to the kingdom economic policy without Taking profit in to consideration or as one of its objective.

\section{The Central Bank Functions}

To be able to achieve its goals the central bank had developed his duties and responsibilities to in the present time as follows: 


\subsection{Issuing Bank Notes and Coins}

The central bank is regarded as the authorized party who can Issue the banknotes and coins in Jordan, provides the national economy with its needs of coins and banknotes and the necessary reserve Forint, also getting back the old bank notes and coins and Issue new ones Instead of it and souvenirs.

\subsection{Holding the Kingdoms Reserve of Gold and Foreign Exchange and Managing It}

here the central bank also do this Job, by Determining the suitable Investment choices and the ratios and reserve components in away that quarantines the exchange, liquidity and profitability For these reserves that represent to the basis of Jordan Dinar Foreign exchange, stabilization. The bank follows flexible policy here that suits any new developments happening in the exchange or international Finance markets.

\subsection{Being as a State Bank for the Government and Public Sector and as a Financial Agent}

The central bank works as a financial agent representing the government and public Establishments where it has the Earnings and expenses accounts and letters External remittances and of credits besides managing and carrying out credit agreements, Trade agreements and offering loans for the treasury. Also it manages the internal establishments and the country, managing the kingdom equity in the International and regional Financial Institutions and the pigment agreements to with other countries.

\subsubsection{As a Bank for Licensed Banks and the Credit Agencies}

Upon that the central bank hold the other banks Deposits and providing them with Facilities by Debts, rediscount and ban kink risks services saving Deposits, selling Treasary bills the external payments and reconciliation. The authentic of licensing bank work and subsidiaries or branches and accepting its deposits credit and credit Facilities as a bank for the credit agencies.

\subsubsection{Comptrolling or Controlling the Banks to Guarantee Its Financial Positions Safe}

The central bank is responsible for controlling and supervising the bank system in away that keeps it safe and stabilized to safeguard the Depositors and stock holders money by Improving paid capitals the capital efficiency, Assets, profitability, managing it, and applying International Accounting standards related to banks organization regarding its capital suitableness, Assets, profitability, managing it, liquidity, assuring the Importance of qualification and Training For the banking systems workers to enable them from coping or keeping up to date with all the things of monetary field checks of licensed banks in order the assure its financial conditions soundness.

1) Providing consultations for the government by Determining of fiscal and economic policies and its implementation: The central bank-upon the request of the government or as an Initiative-provides suggestions and recommendations related to the current economic, fiscal and monetary conditions. It participates in planning the economic policies specially those related to the economic development plans. There is also a vital are done between the Jordanian authorities and the International Financial Institutions related to the correction programs of the economy which are applied since 1989.

2) Solving monetary problems and settling economic and local problems: This is achieved by the role given to it according to the law as the party responsible about taking any necessary arrangements to solve any problems and containing its effects and Impact on the Jordanian economy.

3) organizing banking credit: the central bank do anything to affect the credit quantity, quality and cost to achieve monetary stability and economic development by using the available monetary tools of the central bank to manage the credit like entering open market operations determining the obligatory monetary reserve or the discount rate.

Loesides the past roles, the bank played a vital role in Establishing many Financial companies and establishments which played a major role in supporting economic development efforts in the kingdom like Amman exchange, the Jordanian company for refinancing properties, the Jordanian company for debt guaranteeing deposits...etc.

\subsection{The Monetary Policy of the Central Bank of Jordanian}

The central bank of Jordan uses the following Instruments to achieve it's aims related to the authorized banks:

1) Organizing the credit quantity, type and cost as are spoons for the economic growth, and monetary stability demands.

2) Working as a bank for authorized banks. 
3) Comp trolling the banks in away that safeguards its financial position and owners equity.

\subsubsection{These are Achieved the Following Instruments}

First: the obligatory monetary reserve

Item (42) of the central bank of Jordan law 23-1971 Deal with the arrangements of the money reserve by the central bank For the authorized banks where article-states the following: " the central bank of Jordan obliges any licensed banks to deposit an obligatory reserve that represents $5-35 \%$ of the deposits and the central bank has the right to use these reserves as a deposit or a current account and they cant be withdrawn without the central bank consent here ${ }^{12}$ and he obliged the licensed banks to hold $60 \%$ of the reserve as a deferred deposit for two days and $40 \%$ as a current account with $8 \%$ as a rate from the date beginning in $1 / 1 / 2002$ here.

Second: the authorized liquidity

Its regardless of the central bank of Jordan weapons based upon the determined rate of liquidity which has anegatine relation with credit quality is regarded as one of the most Important problems facing banking credit operations because of the controversy between profitability and liquidity, so if the central bank aims to decrease credit given by banks, it will rise the liquidity ratio that must be hold by banks but if the vice verse is targeted banks can increase its credit.

The central bank of Jordan had determined the minimum percentage of authorized liquidity to be $30 \%$.

Third: credit ratio/deposits

The central bank's objective of determining this ratio is to determine the permitted credit for the authorized banks relative to the deposits size, so that authorized doesn't exceed $70-90 \%$ of the ratio for the period 1974-1995 according to the economic conditions at that time bet in 1995 the central bank abandoned this radio as a way of managing monetary policy indirectly.

Fourth: credit ceilings and concentrations

The credit ceiling and concentrations management has been a targeted tool for the monetary instruments to that was adopted by the central bank in 1992 when the bank targeted organizing the credit facilitations size to be within the limits, so the bank determined the permitted ratios for the Jordan dinar and other foreign exchange given by the authorized banks not to be more than ten times of the capital and the held reserves by the central bank. Facilitations determined here are debts, loans and current accounts with all types of it, discounted notes payable and any other kind of facilitations or bank investments in loans or stocks, and we mean by" capital and reserves" to be the paid capital and the obligatory and voluntary reserves" besides the periodical profits. In 1995 the central bank had obanoned this ratio here.

Fifth: interest rate

The interest rate represents the amounts charged by the banks for loans and facilities given for their clients, so if the monetary policy target was to decrease the credit size the bank Increases the interest rate so that the Debt cost will in crease and the loans given to clients will decrease and the credit process decreases, while if the contrary was the central bank lovers the in tersest rate so the debt cost will because and clients find themselves pushed towards credit and the expansion of credit facilitations will be here.

The Issue of determining the interest rate charged by the authorized banks for loans or given on the deposits isn't the central banks responsibility but the authorized banks responsibility from the year 1990 .

Sixth: rediscount rate

The central bank can affect the credit size by manipulating the rediscount rate, so when it's increased it means managing credit by the banks white the opposite means credit expansion.

Rediscount rate is the interest dealt with between the authorized banks and the central bank, so if the bank wants to increase his money reserves it will ask the central bank to rediscount some of its stacks and bonds he got according to the rediscount rate terms of the central bank of Jordan and the central bank discounts it according to its interest rate which is called the rediscount rate. If the bank increases this rate the authorized banks will charge the cost frits clients by increasing Debts Interest rate so that the credit size will be limited while the opposite happens if the central bank decreases its rechscount rate.

Seventh: open market transactions

The central bank can use the open market operation or transactions as a control for then credit activities in the national economy, here the bank can be as a buyer a seller for the securities and governmental banks in order to 
control the money supply according to the economic situation, so when there is a low level of economic activity and states suffer from recession the central bank will Intervene as a buyer for the securities and governmental bonds so that the money supply and money accounts for commercial banks will Increase, upon that its creditability will Improve besides the Individuals Increase For goods find services which will leverage the employment and production, while if the Inflation dominated the economic conditions the bank will Intervene by selling the secanties and bands so that the money supply will Decrease and bank accounts also, hence the creditability will decrease at this case.

Eight: bank loans (facilities)

The central bank of Jordan provides the authorized or liscenced banks credit facilities after Investigating the bank's need for it and that it got liquid assets that can cover the sum, so the cantrac bank will be the last resort for the bank, besides providing it for any bank having financial or banking troubles that can affect its credit abilities if the bank statements reported losses for two consecutive years and the senses for these losses were verified.

This Facilities Won't be given unless there were correction action that must be taken by the determined period and the two banks agree upon the Debt settlement after that.

Ninth: banks investigation

The central bank authorizes one of his worker or more to check the bank accounts and ledgers to assure its sound financial position and safeguarding the peoples Deposits.

The banks have to prepare semi-annual and annual statements to report its financial operations and positions according to the generally accepted accounting standards, this is done by authorizing anexlernal audit.

From the central bank list of audits-to present his views about the closing accounts reported by the bank and the soundness of it and nullifying the central bank about it if there any faults present at these statements affecting the banks position.

Tenth: bureau control

The central bank obliges the working banks to provide it with all periodical Data like the monthly statement of assets and liabilities according to the form determined by the comptroller of the central bank, then the central bank analyze the statement items like the deposits classification and facilities in order to Judge its commitment to the reties and Instructions of the central bank here.

The central bank also obliges the working banks to provide it with the bank's balance sheet after it's passed by the banks general committee and audited by an authorized audit besides being analyzed by the central bank regarding its financial position.

The central bank orders the working banks also to provide him with a report about the banking risks by giving him a list with all of the clients whose debts or facilities are more than JD 300.00 to collect the data and provide the banks about any client with it when the client asks for more facilities to get Information about his facilities and estimate his ability and any guarantees provided by him (or her) and the probability of any Default here.

The organizing legislations for the Islamic banks work in Jordan:

the items or articles 50-59 of the banks law number 28 (2000) that was Implemented from 1/8/2000 states the articles that organize the Islamic banks work in Jordan, where these new legist lotions the objectives and missions for the Islamic banks represented by providing bank services financing and investment-according-to no Interest rate principle-and those services that aim for Increasing social solidarity that is based on mutual benefit.

The past law dealt with Instructions that must be considered by the Islamic banks when practicing banking activities that are based upon accepted Jurisprudential views and contrary to the interest rate principle.

The law stated also those activities and services rendered by the Islamic bank as follows:

1) Accepting Deposits and bank accounts: whether it was in the Jordanian dinar or other foreign exchange as current accounts or demand accounts or mutual Investment accounts.

2) Investment Portfolios: Which are sawing funds where the bank manages amounts of money provided by clients and investing it connected with certain projects or transactions.

3) Investments: Where the Islamic bank invests his capitals in many things: speculation, participation, investment buying properties, cars, machines or other things based upon the leasing owning method. 
4) Practicing other banking activities not based on usury principle for him or the others inside and outside the kingdom.

5) Working as an agent who manages companies and wells according to Islamic and related legal articles.

6) Establishing companies, holding money and properties selling it, investing, leasing and renting it also in away that guarantees using lands and preparing it for agricultural, Industrial, Tourist or housing activities.

7) As a partner in the social services side aiming for enhancing the social ties between groups and Individuals by providing charities or providing social founds.

8) Establishing self and mutual Insurance Funds for the benefit of the Islamic bank or its clients in different scales.

9) Managing properties and other assets that can be managed on the paid agency basis.

Item (58) of the new banks law stated that the Islamic bank must abide to Islamic laws and this is achieved by having Moslem scholars committee (bay's alraqaba al shariyya) upon the general assembly decision-having hot less than 3 experts and having abiding views for the Islamic bank and do the following:

1) Controlling the bank acclivities and transactions according to Islamic Jurisprudence legislations.

2) Providing consultations regarding the contract statements used in the Islamic bank activities and transactions.

3) Dealing with any Issues upon the orders of the central bank related to times side.

A comparative study for Islamic banks laws Implemented in a group of Arab countries.

The researcher found upon the review of Islamic banks laws Issue from the Arab central like the concept of Islamic banking, what is having ceilings or limited periods within these laws and all of it stated the issue of having an Islamic comp trolling committee who supervises these banks activities.

At the same time, there were some Differences which worth consideration regarding implementation, so in some countries like Yemen and emirates he ergot a specialized controlling unit that controls the Islamic banks that are found by central banks in away that doesn't contradict the Instructions and orders Issued by this unit-whose workers are trained and qualified technically and Islamic ally.

The experiment of Kuwait state was great at this side, because the Islamic banks can buy and sell securities and other syndicates in cooperation with the central bank which must be congruent with Islamic laws. The central bank provides the Islamic apricot not more than 6 months by using tools and methods that copes with Islamic rules. The Central bank can Issue Financial Instruments that copes with Islamic rules and the terms and conditions adopted by the administration of the central bank, baying and selling with other Islamic banks.

Regarding Qatar experiment what was the most noticeable was the method of computing the liquidity ratio which differs from traditional banks and taking into consideration the different balance sizes for these banks when determining the numerator of this ratio (fractions) what's worth mentioning also is the widespread and interest in Islamic banks in Bahrain state, where they have established the organization of Islamic finance Establishments review and accounting in 1990, which is a non-profitable organization, and adopted as a leading International Index for the Islamic Finance establishments regarding:

- Accounting.

- Review.

- And transparency.

And in 2002 they established a liquidity administration center which works with many types of Assets by diversifying risks Islamic banks returns, and the Islamic establishments having surpluses, which can be adopted as Database for bands Investors (short-term Islamic Insurance).

This center aims to Facilitating and creating a banking market that a room for Islamic Financial establishments by managing its assets, enabling them from Investing its surpluses in liquidity and short term (asset supported) Instruments, that are Issued by center. It also works on providing real short term Investment opportunities that are characterized by Islamic credibility that facilitates competing for it and earning money and other Issues that improve the Islamic banks performance tremendously.

The International money market or the Islamic financial service bureau in cooperation with the Islamic bank for development, the credit authority of Bahrain, the central bank of Indonesia, the Lebanese financial services agency (representing Malaysia), central bank of Sudan and the ministry of finance in Brunai the objective for it 
to provide a cooperative structure that guarantees the continuous growth for the Islamic finance market that is based upon Islamic rules and principles, which can be an alternative for the traditional banking system.

\section{Discussing the Results}

After using spss software for analyzing data statistically, the researcher used the following statistical methods:

1) Descriptive Tests, percentages and frequencies.

2) Using Wilcox on test to test hypotheses.

Upon which it tests whether the mean has a value less equal or more then 3 , so if it was $\leq 3$ this will mean accepting the null hypothesis but if it was $\geq 3$ it mean accepting the alternative hypotheses H1, or in away of accepting or rejecting, known as the p-value, if it was less than $5 \%$. The p-value is a test and can be used as an alternative for computerized or tabulated and the comparison between them.

Table 1. The relative distribution for the sample according to gender

\begin{tabular}{ccc}
\hline Gender & Freq & Perc \\
\hline M & 21 & $48 \%$ \\
F & 4 & $16 \%$ \\
Total & 25 & $100 \%$ \\
\hline
\end{tabular}

Looking at table (1) we can infer that the males represent most of the sample respondents with (21) person and a percentage of $(84 \%)$ of the sample, upon that the results show that the majority of the sample views were male because the females were only 4 women $(16 \%)$.

Table 2. The relative distribution for the sample according to age variable

\begin{tabular}{cccc}
\hline Age & Freq & Perc \\
\hline Less than 25 years & 1 & $4 \%$ \\
From 26-35 years & 4 & $16 \%$ \\
From 36- 45 years & 8 & $32 \%$ \\
More than 46 years & 12 & $48 \%$ \\
Total & 25 & $100 \%$ \\
\hline
\end{tabular}

Looking at the past Table (2) we find that most of the study sample were the (46 or more) category with 12 persons and $48 \%$ of the sample ( 25 persons), while the young (less than 25 years) had a very low percentage with $4 \%$.

Table 3. The relative distribution for the study sample according to qualification

\begin{tabular}{cccc}
\hline Age & Freq & Perc \\
\hline Diploma or less & 7 & $28 \%$ \\
Bachelor & 14 & $56 \%$ \\
Master & 3 & $12 \%$ \\
Doctorate & 1 & $4 \%$ \\
Total & 25 & $100 \%$ \\
\hline
\end{tabular}

Looking at table (3) we find that most of the study respondents are bachelor holders with 14 and a percentage of $(56 \%)$ while the doctorate holders were the least with one person and $4 \%$ percentage.

Hypotheses testing and analyses:

The first hypothesis: the first hypothesis stated the following: 
Ho: there is no statistical significant relation between implementing a common controlling policy for Islamic and traditional banks and the Islamic banks performance efficiency.

Table 4. The means and standard deviations for the participants responses regarding the relation between implementing average control policy for both Islamic and traditional banks and the efficiency of the Islamic banks performance

\begin{tabular}{|c|c|c|c|c|c|c|c|c|}
\hline Item & $\begin{array}{c}\text { Very } \\
\text { impact }\end{array}$ & Impact & Neutral & Little & $\begin{array}{c}\text { Non } \\
\text { impacting }\end{array}$ & Mean & S.D & Pvalue \\
\hline $\begin{array}{l}\text { Holding an } \\
\text { obligatory reserve } \\
\text { by the Islamic banks } \\
\text { as the traditional } \\
\text { banks at the central } \\
\text { bank }\end{array}$ & 40.0 & 44 & 4 & 8 & 4 & 4.08 & 1.077 & .020 \\
\hline $\begin{array}{l}\text { Holding the same } \\
\text { liquidity percentage } \\
\text { as the Traditional } \\
\text { banks }\end{array}$ & 36. & 36 & 12 & 12 & 4 & 3.69 & 1.166 & 0 \\
\hline $\begin{array}{l}\text { The same } \\
\text { components of the } \\
\text { liquidity ratio by the } \\
\text { Islamic bank as } \\
\text { other banks }\end{array}$ & 16 & 44. & 28 & 4 & 8 & 3.56 & 1.083 & 0 \\
\hline $\begin{array}{l}\text { The central bank } \\
\text { abandon for the } \\
\text { credit/deposit ratio }\end{array}$ & 28 & 24 & 20 & 20 & 8.0 & 3.44 & 1.325 & 0 \\
\hline $\begin{array}{l}\text { The non } \\
\text { determination of the } \\
\text { credit size provided } \\
\text { by Islamic bank } \\
\text { relative to capital }\end{array}$ & 28 & 28 & 12 & 24 & 8 & 3.44 & 1.325 & 0 \\
\hline $\begin{array}{l}\text { The non } \\
\text { determination for } \\
\text { the credit earnings } \\
\text { achieved by the } \\
\text { Islamic banks }\end{array}$ & 28 & 36 & 16 & 16 & 4 & 3.63 & 1.18 & 0 \\
\hline $\begin{array}{l}\text { The non } \\
\text { determination for } \\
\text { the earnings the } \\
\text { Islamic banks } \\
\text { charge for their } \\
\text { accounts }\end{array}$ & 28 & 20 & 16 & 24 & 12 & 3.28 & 1.149 & 0.640 \\
\hline $\begin{array}{l}\text { The Islamic banks } \\
\text { competition for the } \\
\text { traditional banks }\end{array}$ & 320 & 24 & 20 & 8.0 & 16 & 3.46 & 1.447 & 0 \\
\hline
\end{tabular}

The first hypothesis had Dealt with (8) questions based upon the means and standard deviations and the-p-value for it.

By studying the first hypothesis data we find that the study respondents for the two Islamic banks in Jordan had a response mean more than 4 and a (P-value) $=020$ which means the demand for Islamic banks to hold an obligatory reserve the same as the traditional banks and there is no favourlism for the Islamic banks regarding this ratio and this was the case for all the hypothesis items which had a p-value less than $5 \%$ which means that the results show that there is a significant statistical relation between bowing a unique control policy for Islamic and Traditional banks and the Islamic banks performance a efficiency which means Accepting the H1 hypothesis. 


\subsection{The Second Hypothesis Discussion}

H0: There isn't any statistical significant relation between the Islamic banks performance and not commenting.

H1: There isn't any statistical significant relation between the Islamic banks performance and not commenting.

The second hypothesis discussion Included (5) questions so that the means, standard Deviation and the p-value were calculated for it.

By analyzing the questionnaire Data regarding the second hypothesis we found that the study respondents called for adopting different tax rate for the Islamic and traditional banks and making more room for the Islamic banks by permitting it the establishment of companies and owning transferred and non transferred assets beside managing the others properties.

Table 5. Means and standard deviations for the study participants' responses about the relation between the Islamic banks performance and the disobedience of the central bank requisites

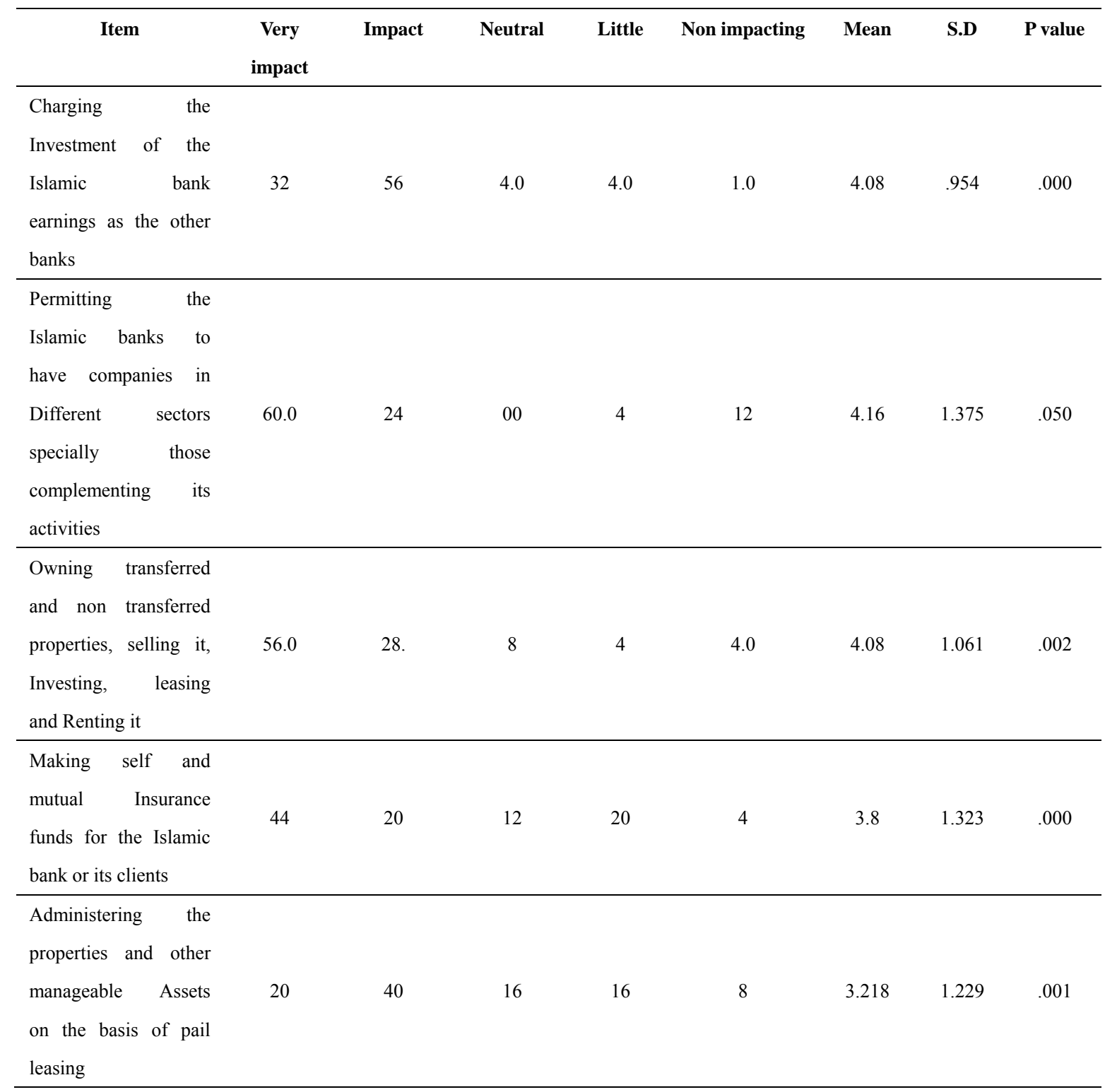

And this is reflected by the mean which had a value more than 4 and O.P. value less than $5 \%$ here we can infer trat there is a relation between the Islamic bank paformance and the disobedience of the central bank law requisites which means accepting $\mathrm{H} 1$. 


\subsection{The Third Hypothesis Discussion}

H0: there isn't any statistical significant relation between solving the problems of the Jordanian Islamic banks by applying the law adopted in other countries.

H1: there isn't any statistical significant relation between solving the problems of the Jordanian Islamic banks by applying the law adopted in other countries.

The third hypothesis Included (3) questions, so that the means, standard Deviation and p- value were computed here. Where we concluded that there is areolation between implementing the Islamic bank laws in other countries and reforming those Implemental in Jordan, where the item related to the Join of the central bank of Jordan for the International Islamic council got a mean of 4 and (ap-value=zero) and this was the case for the other items which means accepting the hypothesis because of its impact on Improving the laws Implemented in Jordan.

Table 6. The means and standard deviations for participants' responses about the presence of any relation between solving the Islamic banks problems by applying rules adopted in other countries

\begin{tabular}{|c|c|c|c|c|c|c|c|c|}
\hline Item/ question & $\begin{array}{c}\text { Very } \\
\text { impact }\end{array}$ & Impact & Nutral & Little & $\begin{array}{c}\text { Non } \\
\text { impacting }\end{array}$ & Mean & S.D & P value \\
\hline $\begin{array}{l}\text { The central bank of } \\
\text { Jordan Join for the } \\
\text { international Islamic } \\
\text { council }\end{array}$ & 36 & 40 & 16 & 4 & 4 & 4 & 1.04 & .000 \\
\hline $\begin{array}{l}\text { Reconsidering the } \\
\text { Issue of the capital } \\
\text { efficiency. }\end{array}$ & 24 & 44 & 28 & 0.0 & 4 & 3.84 & .943 & .011 \\
\hline $\begin{array}{l}\text { Specifying or cutting } \\
\text { of sums of the annual } \\
\text { earning for the } \\
\text { Islamic banks as } \\
\text { areserve for bad debts }\end{array}$ & 20 & 60 & 8 & 12 & 0.0 & 3.8 & .881 & .000 \\
\hline $\begin{array}{l}\text { Making self and } \\
\text { mutual Insurance } \\
\text { funds for the Islamic } \\
\text { bank or its clients }\end{array}$ & 44 & 20 & 12 & 20 & 4 & 3.8 & 1.323 & .000 \\
\hline
\end{tabular}

\subsection{Analyzing the Fourth Hypothesis}

H0: there isn't any statistical significant relation between applying the suggestions regarding Islamic banks and Improving its performance.

The fourth hypothesis Included 4 items, so the means, standard deviations and p-value were computed here.

By looking at table (7) we find that the participants responses express their agreement with buying and selling treasury bills according to the Islamic principles and the loans and Investing the surpluses which is reflected by the mean and p-value which is less there 5\% which means accepting the Implementation of these basics because its Impact on the Islamic banks performance. 
Table 7. The means and standard deviations of the participant's responses regarding the possibility of any relation between the suggestions about Islamic banks Implementation and Improving the Islamic banks performance

\begin{tabular}{|c|c|c|c|c|c|c|c|}
\hline Item/question & $\begin{array}{c}\text { Very } \\
\text { impact }\end{array}$ & Impact & Nutral & Little & $\begin{array}{c}\text { Non } \\
\text { impacting }\end{array}$ & Mean & S.D \\
\hline $\begin{array}{l}\text { Not buying or selling the } \\
\text { governmental securities Issued by } \\
\text { the central bank of Jordan on behalf } \\
\text { of the treasury like the treasury } \\
\text { bills, Deposit or the treasury bonds }\end{array}$ & 32 & 24 & 12 & 8 & 3.6 & 1.29 & 2.00 \\
\hline $\begin{array}{l}\text { Don't deal with the rediscount rate } \\
\text { for the control bank }\end{array}$ & 40 & 20 & 12 & 24 & 4 & 3.68 & 1.345 \\
\hline $\begin{array}{l}\text { Not getting any loans from the } \\
\text { central bank even if it is necessary }\end{array}$ & 4.0 & 16 & 4 & 28 & 12 & 3.44 & 1.557 \\
\hline $\begin{array}{l}\text { In cooperation of the Islamic banks } \\
\text { with the central bank by providing } \\
\text { a deposit account to provide the } \\
\text { needed liquidity or investing the } \\
\text { surpluses }\end{array}$ & 32 & 36 & 8.0 & 16.0 & 8 & 3.66 & 1.314 \\
\hline
\end{tabular}

Table 8. A summary for testing by pothesis

\begin{tabular}{|c|c|c|c|c|c|c|}
\hline Item/ question & Mean & S.D & $\mathbf{T}$ & DF & P. value & Resalt \\
\hline $\begin{array}{l}\text { These isn't statistical significant relation } \\
\text { between implementing a unique control } \\
\text { policy for the Islamic and traditional } \\
\text { banks and the efficiency of the Islamic } \\
\text { banks performance }\end{array}$ & 3.605 & .6541 & 27.5 & 24 & .011 & $\begin{array}{c}\text { Reject } \\
\text { H0 }\end{array}$ \\
\hline $\begin{array}{l}\text { These isn't statistical significant relation } \\
\text { between implementing a unique control } \\
\text { policy for the Islamic banks Performance } \\
\text { and non complance to the law Issued by } \\
\text { the central bank }\end{array}$ & 3.96 & .7325 & 27.02 & 24 & .007 & Reject $\mathrm{H} 0$ \\
\hline $\begin{array}{l}\text { These isn't statistical significant relation } \\
\text { between implementing a unique control } \\
\text { policy for the solving Problems facing } \\
\text { Jordanian Islamic banks by applying laws } \\
\text { form other countries at this case }\end{array}$ & 3.960 & .7234 & 24 & 267 & .002 & Reject $\mathrm{H} 0$ \\
\hline $\begin{array}{l}\text { These isn't statistical significant relation } \\
\text { between Implementing the suggestions } \\
\text { regarding Islamic banks and enhancing } \\
\text { the Islamic banks position }\end{array}$ & 3.60 & 1.038 & 17.3 & 24 & .000 & Reject H0 \\
\hline
\end{tabular}

\section{The Results}

1) There is an Impact of the central bank of Jordan Policies on the Islamic traditional banks performance.

2) It appears that the controlling policies practiced limit the Islamic banks for some level and its efficiency in achieving its goals and weakening the expected performance (by the study respondents) for it. 
3) There is a difference between the laws adopted in Jordan and those adopted in other Arab and Islamic countries which is reflected by the favors of joining the Islamic banks organization represented by the Islamic International council.

4) Based upon fourth hypothesis we realize that there are many traditional investment venues not available for Islamic banks as it is for the traditional banks, which result in surpluses and lowering the return.

5) There is an Impact on Jordanian Islamic banks as a result of non compliance to the law requirements Issued by the central banks.

6) We can solve many problem facing Islamic banks by adopting the suitable legal Items Package.

7) The performance could be enhanced by submitting the operational procedures for a system that is based upon the suggestions suiting Islamic banks.

\section{Recommendation}

At the end of this research we would like to present a group of recommendations the Islamic banks would like the central bank to take in to consideration to put for word new policies that will help the Islamic banks to improve its conditions:

1) adopting the obligatory reserve ratio regarding current deposits for the Islamic banks like the traditional banks while those related to the Investment accounts it must be Decreased because the Islamic bank doesn't guarantee its Deposits and Putting forward a plan for calculating liquidity ratio in away suiting the Deposits and assets dealt with by Islamic banks.

2) Taking into consideration any alternative standards and Instruments regarding the creditor role according to Islamic laws principles and providing the necessary facilities as good loans when necessary so if the liquidity position still a problem or there is a surplus the Islamic bank will provide it as a good Debt for the central bank as it is and for the sure penciled too.

3) We can find a mutual liquidity fund that Islamic countries can participate in it by the non Investing accounts and using the sum in providing liquidity for the Islamic bank at the deficit condition based upon good loan basis or speculation or company as the standardards determined here.

4) The central bank cons elevation for the major Difference between the Islamic banks budget and the traditional bank budget so that there must be a list or a special structure for the assets and liabilities prepared for the Islamic bank different from that for the traditional banks.

5) The central bank must develop its control Instruments used with the Islamic banks taking in to consideration the nature of the activities for it which based on the nature of the activities for it which based on the principle of partnership and speculation, consequently developing new methods or alternatives that help in limiting the number of problems facing the Islamic banks.

\section{References}

Almalqi, A. Al. (2002). Islamic banks the experience between Jurisprudence, law and Implantation (1st ed.). Almarkaz allhaqafi al Arab, Casablanca.

Almasri, A. S. (1972). The Islamic economic theory egyplain Anglo Lib. Curio.

Shabadeh, M. (1994). The relation between Islamic and central banks. The first conference about the Jurisprudential current Issues, university of Jordan.

Shawish, W. (2000). The relation between Islamic banks and the central bank. Alshrqa University conference, Alsharqa.

Shebadeh, M. (2002). The relation between Islamic and central banks. The conference of the Arabic academy for financial and banking sciences-Towards an Integrated Islamic banking system, Jordan.

Trad, I., \& Abbad, J. (2004). The financial and banking legislations in Jordan (3rd ed.). 